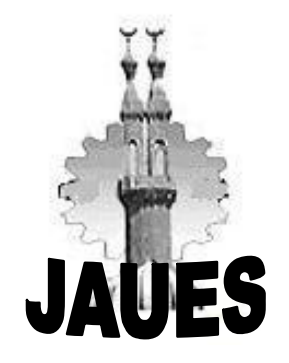

Journal Of Al-Azhar University Engineering Sector

Vol. 14, No. 51, April, 2019, 461-468

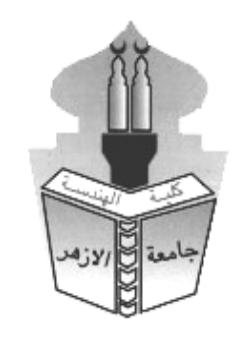

\title{
ASSESSMENT OF SOIL HEAVE STABIZATION USING SALTY WATER TECHNIQUE
}

\author{
Mahmoud Abo Bakr EI Sideek \\ Civil Engineering Dept., Al-Azhar University, Nasr city, Cairo, Egyr
}

\begin{abstract}
Cyclic of heave and settlement of expansive represent one of the main reasons to considerable damages of structures, roads and highways. In Egypt there are many areas containing such expansive soils especially at the arid and semi-arid lands. Some studies used salty water with various concentrations to minimize the swelling behaviour of expansive clayey soils.

In this paper an evaluation for the effectiveness of this technique was carried out based on series of lab experimental tests. Prepared remolded samples were treated with different concentration of salt water and the swelling behaviour, engineering properties, and heave parameters were studied using one-dimensional oedometer test. The effect of potable water on the dried-pretreated sample with salty water was also investigated. The results of the study indicated that, salt water treatment may be unpractical technique. Inundation with salty water may apparently minimize soil heave, however, soil treatment should be applied all through the lifespan of the structure, otherwise, when dry treated soil is subjected to seepage of fresh water, it may yield higher swelling potential.
\end{abstract}

Keywords: Salty water, Salt water treatment, Oedometer test, Expansive soil.

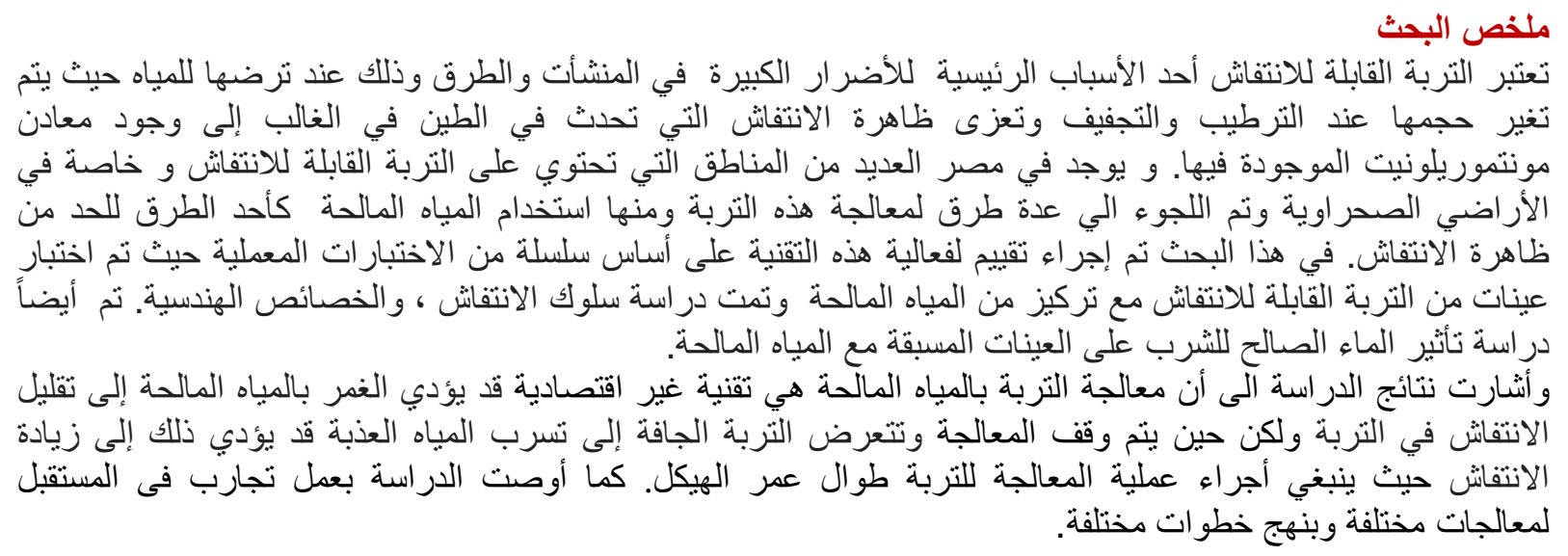

\section{INTRODUCTION}

The expansive soil is distinguished by its high/drying volume change upon wetting and loco. Its treatment is necessary as its clay particles attract moisture and adheres on it to produce considerable volume increase of soil. The high swelling or expansion phenomenon in clays is predominantly attributed to the existence of montmorillonite minerals in clay particles. Expansion so as shrinkage can cause damage to structures above similar soil 
Traditional methods for treatment of expansive soil do not offer a permanent heal. Traditionally, ineffective costly methods are implemented to minimize the volume change of expansive soil, however, most of these methods seem to be uneconomic; destructs environment and do not fix the problem permanently.

This research is focused to evaluate the effectiveness of minimizing expansive soil heave by inundation with salty water. 10 compacted samples were prepared with $\gamma_{\mathrm{d}}=17 \mathrm{kN} / \mathrm{m}^{3}$ and with different testing periods.

The basic concept behind chemical stabilization for expansive soil is that, expansion occurs because of absorption water molecules in the diffuse double layer through three possible mechanisms, the stabilization works on the concept of introducing cation of high valence than that of water, which gets attracted to the clay minerals and brings clay minerals closer together (Mahesh et al., 2017).

Prithiviraj et al. (2017) reported that, the soil - salinity interactions changes the soil behavior, it is mainly due to types of cations in saline water and types of clay mineral in soil layers. Seawater had a strong impact especially on the montmorillonite clay type. Thus the effects of pollutants on soil are complex; and can be studied by understanding the factors such as ion exchange (cation exchange and anion exchange) or nature of pore fluid (electrolyte concentration, dielectric constant, acidity and alkalinity).

Some studies investigated the impact of water salinity on the geotechnical characteristics of expansive soils (Arumairaj and Sivajothi, 2011, Otoko, 2014; Bale et al, 2015; Rajkumar et al., 2017, Souhila, 2018), using different concentration of $\mathrm{NaCl}$ (i.e. $0,2,4,6$, and $8 \%$ ) they found that, atterberg limits decreased by increasing salt content, while the maximum dry unit weight increased by adding solute water.

Elmashad (2016) studied the effect of adding salt water on the swelling characteristics of expansive soil, the results showed that increasing the salt concentration results in a major decrease in the swelling characteristics. Some of these studies indicated that, the most effective salt concentration is about $20 \%$ after which the increase in salt concentration seems to be of minor effect.

Sultani and Estabragh (2015) found that, The use of high concentration of $\mathrm{NaCl}$ solution $(250 \mathrm{~g} / \mathrm{L})$ acted as a sodicity agent while the use of $50 \mathrm{~g} / \mathrm{L} \mathrm{NaCl}$ solution acted as a salinity agent. As a result , the overall swelling potential was seen to be greater for soil samples prepared with $250 \mathrm{~g} / \mathrm{L} \mathrm{NaCl}$ solute compared to distilled water and $50 \mathrm{~g} / \mathrm{L} \mathrm{NaCl}$ solution, respectively. Therefore, the use of low concentrations of $\mathrm{NaCl}$ solution can act as an additive stabilizer agent, that is not only economical compared to traditional methods of stabilization (for example the use of cement, lime and fly-ash) but also widely available in most arid and semi-arid regions.

Dubey and Jain (2015) explained that, the intervention of origin electrolyte (sodium chloride dissolved in distilled water) would result in change in the ion exchange capacity, perhaps due to adsorption. The ion concentration reduces the repulsive forces and increases the effective stress leading to flocculation of clay particles which reduces the plasticity.

Some studies investigated the effect of common salt on some geotechnical properties of expansive soil for highway pavement (subgrade) works, by mixing the soil with saline water (Magdi et al., 2016; Durotoye, et al.2016; Arora, et al., 2018). The samples used were air dried then pulverized and sieved through a sieve of $4.75 \mathrm{~mm}$ to eliminate gravel fraction. The soil sample was stored in airtight containers for stabilization. The soil sample kept for stabilization was mixed with sodium chloride solutions of varying concentrations. They found that, treatment of the studied expansive soil has the effect of reducing the values of the geotechnical index properties (liquid limit, Plasticity index and linear shrinkage, free swell index) of the soil and hence its tendency to swell; and increasing the strength characteristics (California Bearing Ratio, Maximum Dry Density and the Unconfined Compressive Strength).

Swell potential of expansive soils is generally determined by one-cycle of wetting. However due to environmental effects, soils in nature are ceaselessly subjected to wetting-drying cycles. It has 
been showed that the number of wetting-drying cycles play an important role in the behavior of expansive soils (Chen, 2013).

4. Experimental Work

10 remolded compacted samples were prepared with $\gamma_{d}=17 \mathrm{kN} / \mathrm{m}^{3}$. One sample (S1) was tested and its swell was taken as reference value. For tested of (S2) to (S4) each sample was tested 3 times to ensure the homogeneity of the results.

\subsection{Sample Material}

Sample blocks of (Soil description) were extracted from a site at the new administrative capital Cairo - Egypt. The blocks were oven dried and pulverized to be in powder form. The dry samples were prepared by compacting soil powder to reach a density of about $17 \mathrm{kN} / \mathrm{m}^{3}$. The prepared samples were with diameter of $63 \mathrm{~mm}$ and height of $16 \mathrm{~mm}$.

\subsection{Soil Properties}

The properties of the investigated soil were determined in the laboratory and its characteristics are listed in table (1).

Table (1) Implemented soil characteristics

\begin{tabular}{|c|c|c|c|c|c|c|c|c|c|}
\hline \multirow[b]{2}{*}{$\mathbf{S}$} & \multirow[b]{2}{*}{ Soil } & \multirow[b]{2}{*}{ Type of water } & \multirow{2}{*}{$\begin{array}{c}\text { Free } \\
\text { swell } \\
\% \\
\left(\mathbf{S}_{\mathrm{f}}\right)\end{array}$} & \multirow{2}{*}{$\begin{array}{c}\text { Specific } \\
\text { gravity } \\
\left(\mathbf{G}_{\mathbf{s}}\right)\end{array}$} & \multicolumn{3}{|c|}{ Atterberg limit } & \multirow{2}{*}{$\begin{array}{l}\text { Density } \\
\mathbf{k N} / \mathrm{m}^{3}\end{array}$} & \multirow{2}{*}{$\begin{array}{r}\text { Water } \\
\text { content } \\
(W c) \%\end{array}$} \\
\hline & & & & & L.L & P.L & P.I & & \\
\hline 1 & \multirow[b]{2}{*}{$\begin{array}{l}\text { Silty } \\
\text { clay }\end{array}$} & Fresh water & 126 & 2.71 & 43.80 & 18.23 & 25.57 & & \\
\hline 2 & & $\begin{array}{c}* \text { Salty water } \\
200 \mathrm{~g} / \mathrm{L} 20 \%\end{array}$ & 73 & 2.45 & 34.18 & 18.80 & 15.38 & 17 & 8.30 \\
\hline
\end{tabular}

$*[(200 g / L)$ Prithiviraj et al. (2017).

\subsection{Experimental Program}

The samples were prepared; figure (1). Samples were treated with different salty water concentration. They were investigated using one-dimensional oedometer.
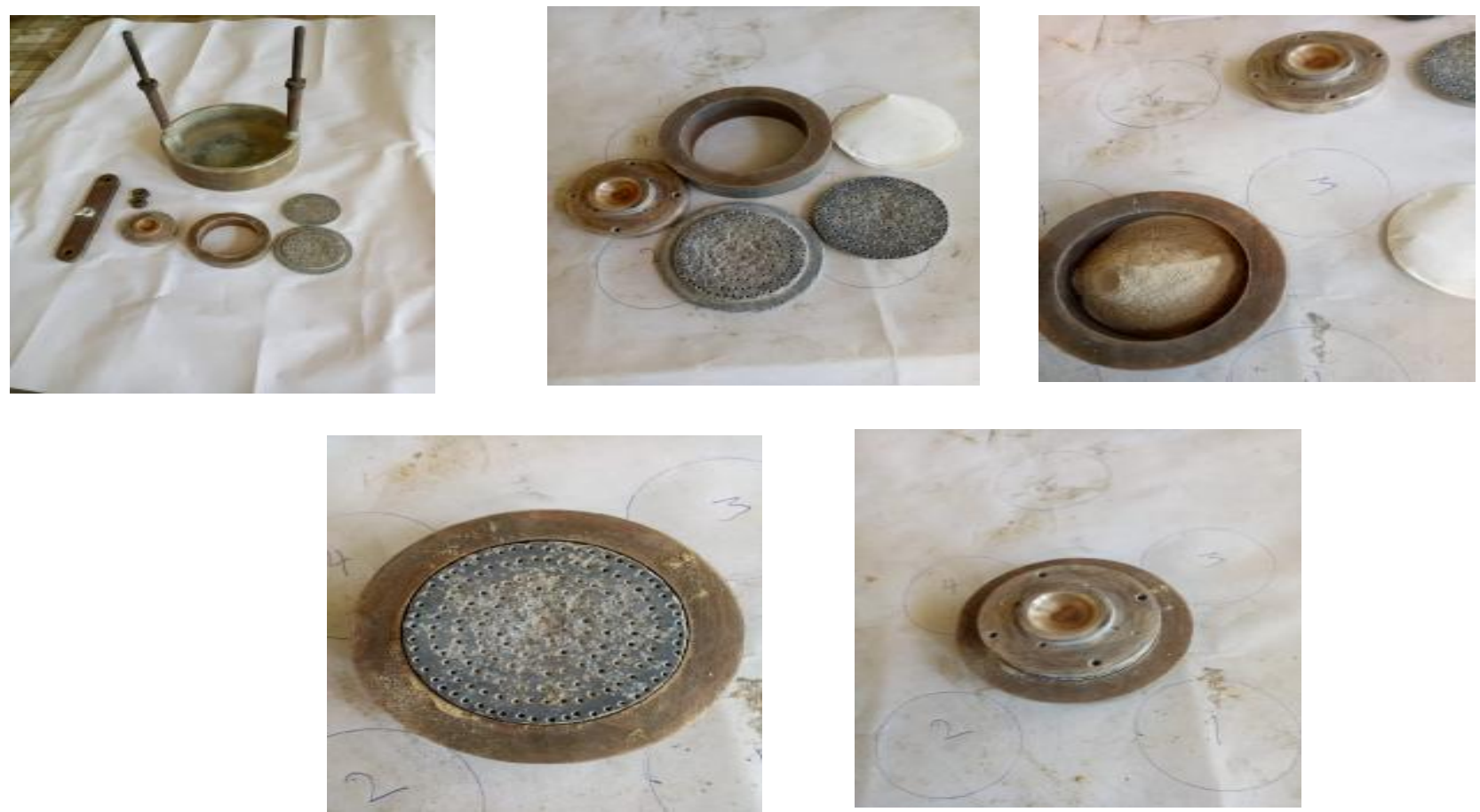

Figure (1) Soil Sample Preparation 
10 samples were examined ( $\mathrm{S} 1$ to $\mathrm{S} 10)$. One of the samples was considered as a reference sample $\mathrm{S} 1$, where it was immersed in fresh water without any treatment. For samples S2 to S10, the salt was dissolved in normal water to make salt solution of salinity $20 \%(200 \mathrm{~g} / \mathrm{L})$.

\subsection{Experimental Procedures Measurements}

Different test procedures and durations were adopted to evaluate the heave of the prepared soil samples in the following conditions: (a) inundation the prepared samples by salty water; (b) gradually drying of the submerged samples, and (c) re-inundation of pretreated dried sample with fresh water.

\subsubsection{Testing with Fresh Water (Sample S1)}

Sample (S1) was immersed in fresh water for one month under seating load of about 12.50 $\mathrm{kN} / \mathrm{m}^{2}$, with continues inundation to compensate for the absorption and evaporation processes in order to maintain the water level constant throughout the test period. The measured heave with time is plotted versus time as shown in Fig. (2) The measured soil heave is about $5.83 \mathrm{~mm}$, i.e. the axial free swell (A.F.S.) is about $36.43 \%$.

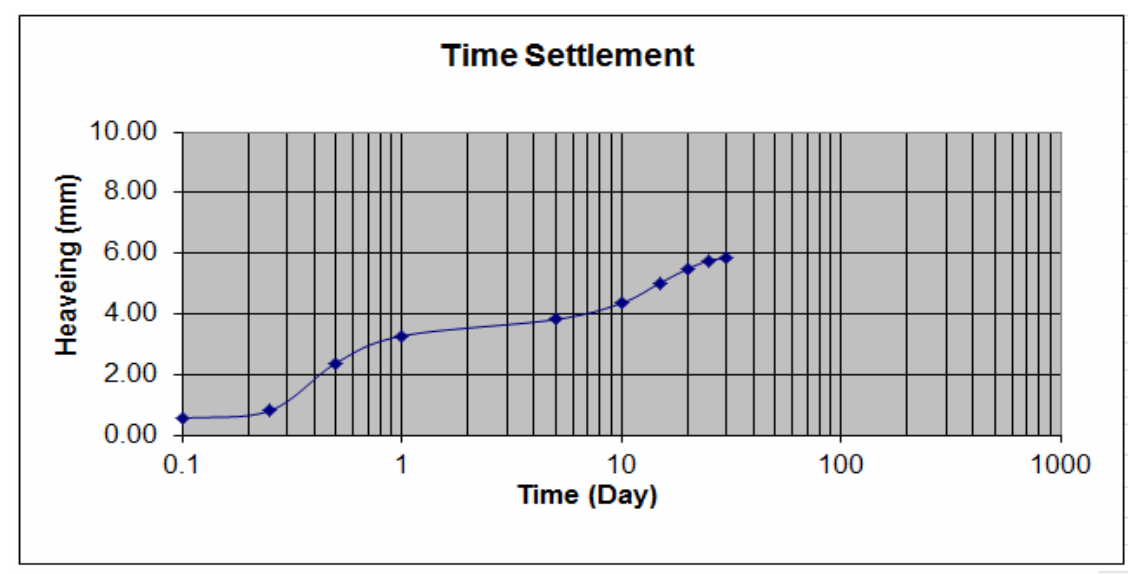

Figure (2) Time- heave relationship for (S1) in fresh water for period of one month

\subsubsection{Testing wet Salty Water-Dry- wet Fresh water (S2)}

Sample (S2) was immersed in saline water with a concentration of NaCL with $20 \%$ (200g/L) for one month. The heave after 4 days reached a value of about $1.72 \mathrm{~mm}$, i.e. the axial free swell was about $10.75 \%$. The reduction in swelling due to soaking with salty water was about $70 \%$ compared to that of sample (S1). However, after removal the salty water and left the sample to dry for about one month, adding fresh water had led the sample to yield additional heave to reach a value of about $6.75 \mathrm{~mm}$, i.e. the A.F.S. becomes about $42.19 \%$ higher than that exerted by fresh water only of sample (S1) by about $15.80 \%$.

Increase in pore water salt concentrations or a growth in exchangeable cation valency will create shrinkage. Desiccation of the soil is the elimination of moisture induced by evaporation. As salt can't be evaporating like water, then the concentration of salts will increase as moisture is eliminated and shrinkage will happen (Vanda, 2014). 


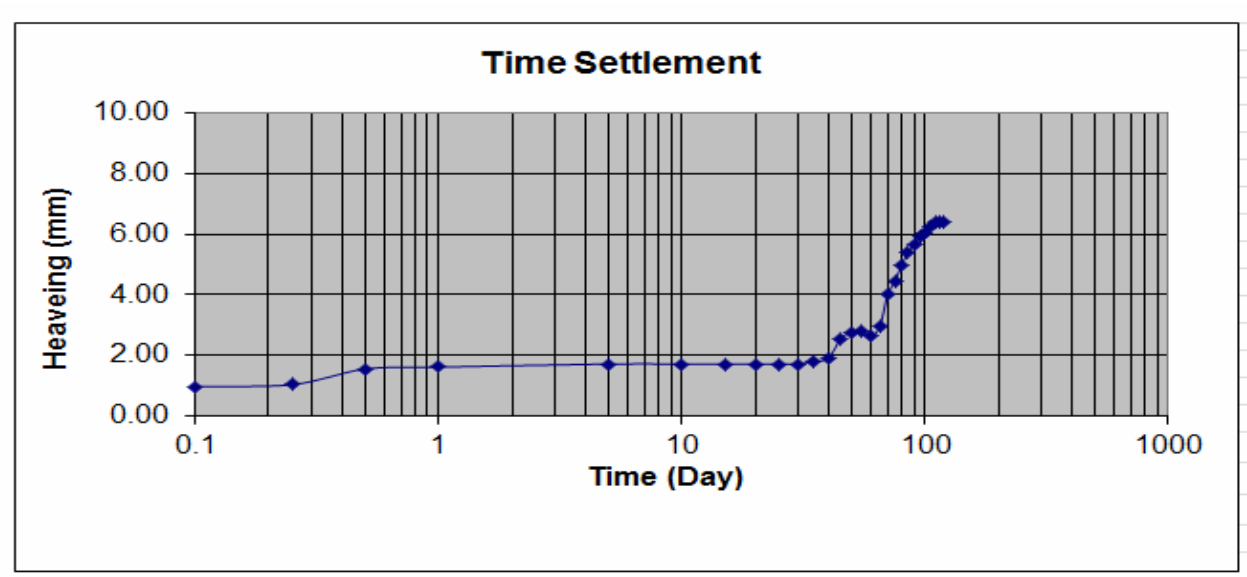

Figure (3) Time- heave relationship for (S2) in salty water for period of one month, then salty water was removed, and sample kept dry for one month, then in fresh water

\subsubsection{Testing wet Salty Water - wet Fresh water (S3)}

Sample (S3) was immersed in saline water with a concentration of NaCL with $20 \%$ (200g/L) for one month. The heave after 4 days reached a value of about $1.84 \mathrm{~mm}$, i.e. the axial free swell was about $11.50 \%$. The reduction in swelling due to soaking with salty water was about $68 \%$ compared to that of sample (S1). However, after removal the salty water and directly adding fresh water had led the sample to yield additional heave to reach a value of about $8.21 \mathrm{~mm}$, i.e. the A.F.S. becomes about $51.31 \%$ higher than that exerted by fresh water only of sample (S1) by about $40.85 \%$.

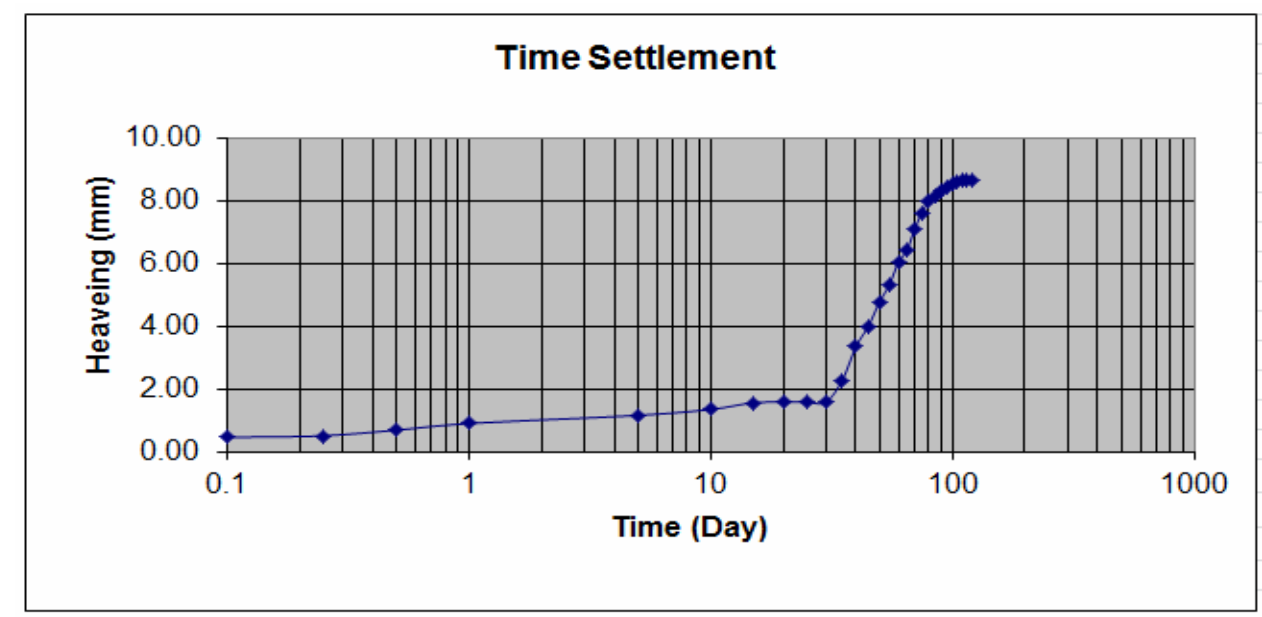

Figure (4) Time- heave relationship for (S3) in salty water for period of one month, then salty water was removed, and then directly adding fresh water 


\subsubsection{Testing wet Salty Water (S4)}

The soil sample (S4) was immersed in salty water with $20 \%(200 \mathrm{~g} / \mathrm{L})$ for one month, only once a time without continuous inundation, i.e. no compensation for water evaporation and sample absorption. The measured heave after one month was about $3.65 \mathrm{~mm}$; the axial free swell in such case was about $22.81 \%$, i.e. an apparent reduction in axial free swell by about $37.40 \%$.

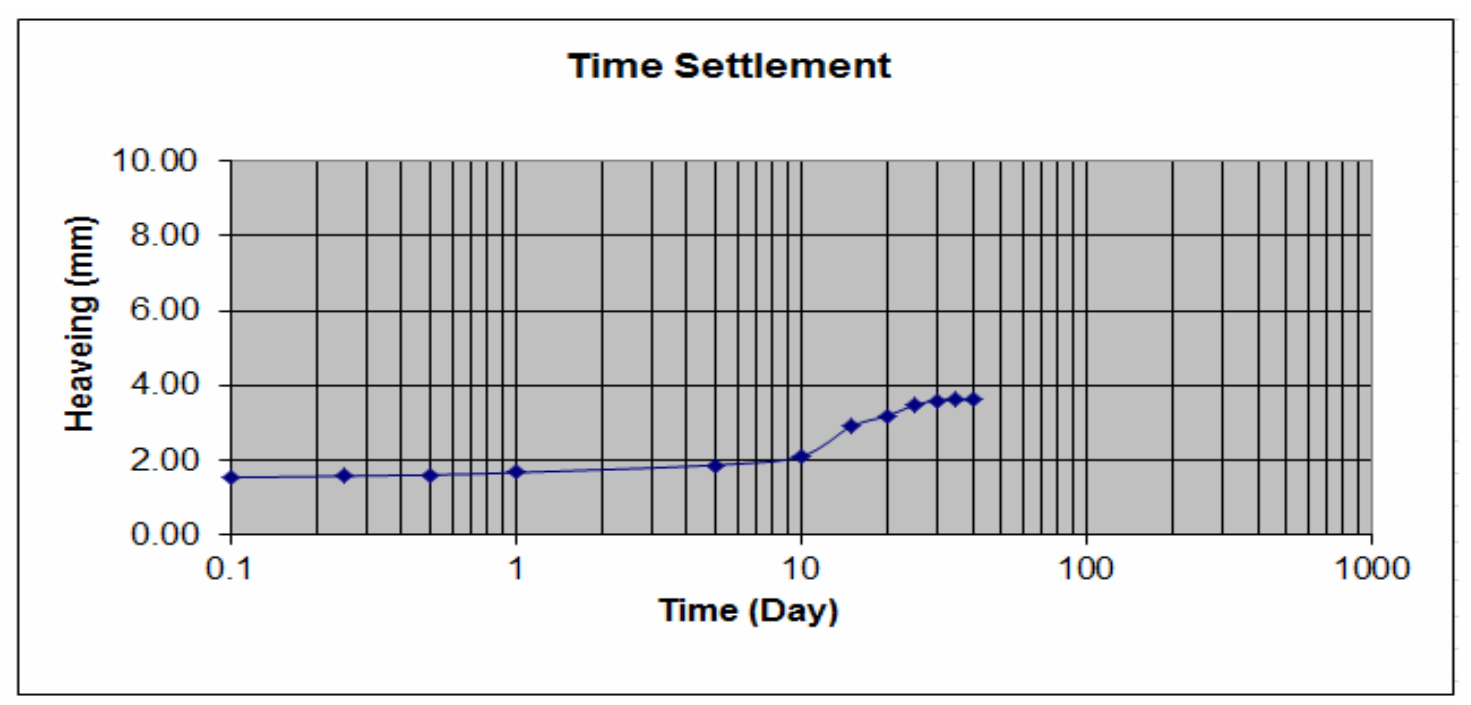

Figure (5) Time--soil heave for sample (S4) in the case of treatment with salty water without continuous inundation

\section{Results Analysis and Discussions}

Change in fine grain soil behavior due to salt contaminants in the absence of strong interaction leading to mineralogical changes can be explained based on changes in the diffuse double layer theory and fabric changes. The amount of swell depends upon the type of mineral present in the soil and concentration of saline solution.

The obtained swelling measurements under light seating load were carried out to simulate the field treatment techniques, and the probable conditions of drying and re-inundation with fresh. The results of sample (S4) represent the field treatment technique followed in some locations in Egypt (El-Dhabi technical report Egypt 2015)], inundation the soil with salty water only once a time, without continuous feeding with salty water. This technique had led to apparently reduction in soil swelling potential $(18.25 \%)$ compared to that of sample (S1) immersed with fresh water $(36.43 \%)$, i.e. a reduction by about $37.40 \%$.

The treatment technique with conditions followed in testing sample (S4), where the sample was firstly treated as sample (S1) with salty water, and then left until the soil becomes semi-dry after practically salty water is fully absorbed and/or evaporated, in such case if the soil is subjected to re-inundation by seepage of fresh water, the measured swelling was about $40.05 \%$, i.e. higher than the apparently swelling of (S4) by about $84 \%$, and higher than that treated by fresh water (S1) by about $37.40 \%$

In case of assuming field conditions for pretreated sample with fully absorption and/or evaporation with wet soil (S3), due to the exchange ions by concentration of salt on the clay particles, and then with re-inundation with seepage fresh water, the measured swelling percent was about $51.31 \%$, i.e. higher than the apparently reduced swelling percent of (S4) by about $125 \%$, and that inundated with fresh water by about $40.85 \%$. The observations of the previous analysis are summarized in Table (2): 
ASSESSMENT OF SOIL HEAVE STABIZATION USING SALTY WATER TECHNIQUE

Table (2) Comparison between various treatment techniques followed for testing the samples

\begin{tabular}{|c|l|c|c|c|}
\hline Sample & \multicolumn{1}{|c|}{ Treatment Technique } & Adding water & A.F.S\% & Change \\
\hline (S1) & $\begin{array}{l}\text { Treated with fresh water for one } \\
\text { month. }\end{array}$ & $\begin{array}{c}\text { continuous water } \\
\text { feeding }\end{array}$ & $36.43 \%$ & $\begin{array}{c}\text { Reference } \\
\text { Sample }\end{array}$ \\
\hline (S2) & $\begin{array}{l}\text { Treated with salty water for one } \\
\text { month- drying for one month- } \\
\text { inundation with fresh water. }\end{array}$ & $\begin{array}{c}\text { continuous water } \\
\text { feeding }\end{array}$ & $42.19 \%$ & $\begin{array}{c}+15.80 \% \\
\text { (Increase) }\end{array}$ \\
\hline (S3) & $\begin{array}{l}\text { Treated with salty water for one } \\
\text { month- drainage of free salty water- } \\
\text { then directly inundation with fresh } \\
\text { water. }\end{array}$ & $\begin{array}{l}\text { continuous water } \\
\text { feeding }\end{array}$ & $51.31 \%$ & $\begin{array}{c}+40.85 \% \\
\text { (Increase) }\end{array}$ \\
\hline (S4) & $\begin{array}{l}\text { Treated with salty water for one } \\
\text { month only once a time. }\end{array}$ & $\begin{array}{l}\text { Without continuous } \\
\text { water feeding }\end{array}$ & $22.81 \%$ & $\begin{array}{c}-37.40 \% \\
\text { (Decrease) }\end{array}$ \\
\hline
\end{tabular}

\section{Conclusions and Recommendations}

The following conclusions and recommendations are based on the experimental results carried out in this study, to evaluate the effect of using salty water technique to minimize the swelling potential of expansive clayey soil, the conclusions are as follows:

1- Inundation of swelling clayey soils by salty water without continuous feeding to compensate the effect of absorption and/or evaporation, may lead to change and increase the ion concentration with salt on the clay particles, and consequently higher ability for expansion.

2- When dry or semi-dry pretreated soil with salty water was continuously immersed in fresh water, the swelling percent increased by about $84 \%$ to $125 \%$.

3- Salt water as chemical stabilization agent may show periodically reduction in swelling. Inundation with salty water may apparently minimize soil heave, however, soil treatment should be applied all through the lifespan of the structure, otherwise, when dry treated soil is subjected to seepage of fresh water, it may yield higher swelling potential.

4- Some studies were based on mixing the swelling soil particles with different percentage of salt concentration in fresh water, and testing prepared compacted samples. Such technique may in general be unpractical, as it may only be used as subgrade for high way roads, if the hard swelling soil can be pulverized into powder, and the mixed soil can be practically compacted, as well as, the pavement will acts as sealing against seepage of water.

\section{7- ACKNOWLEDGMENT}

The experimental work of this study was carried out at the Soil Mechanics Laboratory of civil Eng. Department, Al-Azhar University, thanks for the laboratory staff and technicians, and also for the help of material lab technicians.

\section{REFERENCES}

1. Arora, A. P. S, Das K., Sengupta D., and Maity J. (2018). "Effect of Sea Water on the Geotechnical Properties of Cohesive Soil". International Research Journal of Engineering and Technology (IRJET), Volume: 05 Issue: 05 | May, pp.3003-3006.

2. Arumairaj, P.D., and Sivajothi A., (2011), "Effect of Sea Water on Expansive Soils" EJGE, Vol. 15 [2011], Bund. J, pp. 425-43.

3. Bale N. k., Jeevana S. and Uday, K.V. (2015). "The Effect of Salinity on Geotechnical Properties of Expansive Soils, International Journal of Innovative Research in Science, Engineering and Technology, An ISO 3297: 2007 Certified Organization, Vol. 4, Issue 7, July 2015.

4. Dubey P. and Jain R. (2015)," ffect of Common Salt $(\mathrm{NaCl})$ on Index Properties of Black Cotton Soil", International Journal for Innovative Research in Science \& Technolog | Volume 2 | Issue 02| July, PP.75-79. 
5. Durotoye, T.O, Akinmusuru, J.O, Ogbiye, A.S, Bamigboye, G.O (2016), Effect of Common Salt on the Engineering Properties of Expansive Soil, International Journal of Engineering and Technology Volume 6 No.7, July, PP.233-241.

6. Elmashad M. E. (2016). "Effect of seawater on consistency, infiltration rate and swelling characteristics of montmorillonite clay", Housing and Building National Research Center, HBRC Journal, (2016) 12, 175-180.

7. MAHESH K., RAMA K. M., YASWANTH KUMAR, V. (2017)," Effect Of Saline Water on Geotechnical Properties of Expansive Soils, International Journal of Engineering Research-Online, Vol.5. Issue.1. January-February, pp. 202-205.

8. Otoko, G. R. (2014). "The Effect of Salt Water on the Physical Properties, Compaction Characteristics and Unconfined Compressive Strength of a Clay, Clayey Sand Aand Base Course", European International Journal of Science and Technology Vol. 3 No. 2 March, 2014.

9. Prithiviraj, D.., Ashwin kumar S. P., Pranap N., Aravindaraj M., (2017)." Effect of Sea water intrusion on Geotechnical Behavior of soil- A review", International Journal of Scientific \& Engineering Research Volume 8, Issue 10, October, pp. 30-36.

10. Rajkumar V., Ankur D., Akash J. (2017) "Effect of Common Salt (Nacl) on Index Properties of Black Cotton Soil (BCS)" International Journal for Research in Applied Science \& Engineering Technology (IJRASET),Volume 5 Issue V, May 2017, 23219653.

11. Shirazi S.M., Wiwat S., Kazama H., Kuwano J., Shaaban, M.G. (2011). "The Salinity Effect on Swelling Characteristics of Compacted Bentonite", Environment Protection Engineering, Vol. 372011 No. 2.

12. Soltani A., and Estabragh, A.R. (2015), "Treatment of expansive soils with quality saline pore water by cyclic drying and wetting, Desert 20-1, pp.73-82.

13. Souhila R. B., Ghania B., Djenette M., Benayoun et. F, (2018). "Use of Salt Compounds for the Stabilization of Expansive Soils, Discovery Publication.www.discoveryjournals.org, pp.250-256.

14. Vanda Y. (2014), "Effect of Pore Water Chemistry on Hydro-Mechanical Behavior of Compacted Expansive Clay", M. Sc. Thesis, Eastern Mediterranean University, Gazimağusa, North Cyprus, PP. 18.

15. Chen, R., C. (2013). "Impact of wetting-drying cycles on hydro-mechanical behavior of unsaturated compacted clay”. Applied Clay Science 86: pp. 38-46. 